\title{
PENERAPAN PENGENDALIAN KUALITAS DENGAN MEWMA DAN FUNGSI DENSITAS KERNEL MULTIVARIAT (Studi Kasus: PT Sukorejo Indah Textile Kab. Batang)
}

\author{
Mifta Fara Sany ${ }^{1}$, Rukun Santoso ${ }^{2}$, Arief Rachman Hakim ${ }^{3}$ \\ 1,2,3 Departemen Statistika FSM Universitas Diponegoro \\ e-mail : mifta.sany97@gmail.com
}

\begin{abstract}
In an era of industrial revolution 4.0, technology is increasingly sophisticated, requiring companies to be more creative. Product quality control is an effort to minimize the defective products produced by the company. The production of weaving sarongs at PT SUKORINTEX pays attention to the accuracy of the length and width of the sarong to conform to the standards set by the company. To find out the quality of woven sarong products at PT SUKORINTEX, analysis was performed using Multivariate Exponentially Weighted Moving Average (MEWMA) control charts and multivariate kernel control charts. The research variable was the characteristics of the X sarongs which is reflected in 2 variates, namely the average length and average width. Based on the results and discussion that has been done, the MEWMA control chart used a weighting $\lambda$ which is determined using trial and error. MEWMA control charts can be said to be stable and controlled by $\lambda=0.1$, Upper Control Limit (UCL) of 14.62943, and Lower Control Limit (LCL) of 0 . Multivariate kernel control chart were declared uncontrolled with $\alpha=0.1$ and level $=0.06130611$ because there were data that was outside the contour. Chart improvement was done by trial and error and obtained a controlled chart results at $\alpha=0.01$ and a level value of 0.03125701 . Based on this case study, the quality control of the average length and width of WADIMOR woven sarong types 30 STR with MEWMA is better than the multivariate kernel density, because MEWMA is controlled and stable in controlling product quality. The results of the MEWMA control chart show a capable process because more than 1 process capability index value is obtained.
\end{abstract}

Keywords: Multivariate Exponentially Weighted Moving Average (MEWMA) control chart, multivariate kernel control chart, process capability.

\section{PENDAHULUAN}

Pengendalian proses statistik adalah alat utama yang digunakan dalam membuat produk dengan benar. Salah satu teknik pengendalian kualitas statistik yaitu grafik pengendali (control chart). Menurut Montgomery (1990), teori umum grafik pengendali pertama kali ditemukan oleh Dr. Walter A. Shewart, yang dinamakan grafik pengendali parametrik. Grafik pengendali parametrik memiliki asumsi bahwa data mengikuti distribusi normal. Selain itu, terdapat alternatif lain, yaitu dengan menggunakan grafik pengendali nonparametrik.

Menurut Montgomery (2009), Multivariate Exponentially Weighted Moving Average (MEWMA) adalah grafik pengendali yang lebih sensitif terhadap perubahan yang lebih kecil. Grafik pengendali kernel multivariat adalah salah satu grafik kendali alternatif yang bersifat nonparametrik. Grafik ini menggunakan fungsi densitas kernel multivariat untuk menaksir nilai batas kontrolnya.

PT Sukorejo Indah Textile (PT Sukorintex) merupakan salah satu perusahaan yang bergerak dalam bidang tekstil dengan Produk utamanya ialah sarung tenun WADIMOR. Pada produksi sarung ini, PT Sukorintex sangat memperhatikan ketepatan panjang dan lebar produk agar sesuai dengan standar ukuran yang telah ditetapkan dari perusahaan. Disini peranan dari pengendalian kualitas diperlukan, agar faktor-faktor yang menyebabkan panjang dan lebar sarung tenun yang tidak sesuai standar dapat diketahui kemudian diminimalisir bahkan dihilangkan. 


\section{TINJAUAN PUSTAKA}

\subsection{Gambaran Umum PT Sukorejo Indah Textile (Sukorintex)}

PT Sukorintex merupakan Perusahaan yang bergerak dalam bidang tekstil, bermerek besar WADIMOR yang memproduksi sarung tenun. Sistem produksi di PT. Sukorintex adalah produksi make to stock dan make to order. Proses produksi pada perusahaan ini dilakukan oleh lima departemen yaitu departemen persiapan, departemen weaving, departemen grey room, departemen finishing dan departemen packaging.

\subsection{Kualitas}

Dalam bidang industri, istilah mutu diartikan sebagai factor - faktor yang terdapat dalam suatu barang/hasil yang menyebabkan barang/hasil tersebut sesuai dengan tujuan kegunaan barang/hasil itu dimaksudkan atau dibutuhkan (Assauri, 1980).

\subsection{Pengendalian Kualitas Statistik}

Pengendalian kualitas adalah aktivitas keteknikan dan manajemen, yang dengan aktivitas itu kita ukur ciri-ciri kualitas produk, membandingkannya dengan spesifikasi atau persyaratan, dan mengambil tindakan penyehatan yang sesuai apabila ada perbedaan antara penampilan yang sebenarnya dan yang standar (Montgomery, 1990).

\subsection{Data Multivariat}

Menurut Haryatmi dan Guritno (2008), data yang diperoleh dengan mengukur lebih dari satu kriteria variabel pada setiap individu anggota sampel disebut data multivariat. Teknik-teknik analisis statistik yang memperlakukan sekelompok variabel kriteria yang saling berkorelasi sebagai suatu sistem dengan memperhitungkan korelasi antar kriteria tersebut disebut metode statistika multivariat.

Tabel 1. Struktur Data Multivariat

\begin{tabular}{ccccc}
\hline \multirow{2}{*}{ Variate } & \multicolumn{5}{c}{ Objek } \\
\cline { 2 - 5 } $\mathrm{X}_{1}$ & 1 & $\mathrm{~J}$ & $\ldots$ & $\mathrm{N}$ \\
$\mathrm{X}_{2}$ & $x_{11}$ & $x_{1 j}$ & $\ldots$ & $x_{1 n}$ \\
$\mathrm{X}_{\mathrm{i}}$ & $x_{i 1}$ & $x_{2 j}$ & $\ldots$ & $x_{2 n}$ \\
$\vdots$ & $\vdots$ & $\vdots$ & $\ldots$ & $x_{i n}$ \\
$\mathrm{X}_{\mathrm{p}}$ & $x_{p 1}$ & $x_{p j}$ & $\ldots$ & $\vdots$ \\
\hline
\end{tabular}

dengan $\mathrm{x}_{\mathrm{ij}}$ adalah nilai pengamatan ke- $j$ dari variate ke- $i$

$\mathrm{i}=1,2, \ldots, p$ dan $\mathrm{j}=1,2, \ldots, n$

\subsection{Uji Distribusi Normal Multivariat}

Uji distribusi normal multivariat dilakukan dengan cara membuat $q-q$ plot dari nilai:

$$
d_{j}^{2}=\left(\mathbf{x}_{j}-\mu\right)^{T} \mathbf{S}^{-1}\left(\mathbf{x}_{j}-\boldsymbol{\mu}\right)
$$

dengan

$\boldsymbol{x}_{\boldsymbol{j}}$ : vektor pengamatan ke-j dengan $\mathrm{j}=1,2, \ldots, n$.

$d_{j}^{2}$ : jarak mahalanobis setiap titik pengamatan ke-j dengan $\mathrm{j}=1,2, \ldots, n$.

Menurut Haryatmi dan Guritno (2008), jika scatterplot ini cenderung membentuk garis lurus dan lebih dari $50 \%$ nilai $d_{j}^{2} \leq \boldsymbol{\mathcal { x }}_{p, 0.50}^{2}$ maka $\mathrm{H}_{0}$ diterima atau dapat dikatakan bahwa data berdistribusi normal multivariat. 


\subsection{Uji Korelasi Variate}

Untuk menguji ada tidaknya keterkaitan antar variate, maka dilakukan uji Bartlett dengan hipotesis sebagai berikut (Morrison, 1990).

Hipotesis

$\mathrm{H}_{0}: \mathbf{R}=\mathbf{I}$ (tidak ada korelasi antar variate)

$\mathrm{H}_{1}: \mathbf{R} \neq \mathbf{I}$ (ada korelasi antar variate)

Statistik Uji :

$\chi_{\text {hitung }}^{2}=-\left\{n-1-\frac{2 p+5}{6}\right\} \ln |\mathbf{R}|$

dengan

$\mathrm{n}$ : banyaknya observasi

$p$ : banyaknya karakteristik

$\mathbf{R}$ : matriks korelasi dari masing-masing variate

$\mathbf{R}$ : determinan matriks korelasi

I : matriks identitas

Sehingga keputusan menerima $\mathrm{H}_{0}$ yang berarti antar variate bersifat saling bebas atau tidak ada korelasi, jika nilai $\chi_{\text {hitung }}^{2} \leq \chi_{\left(\alpha, \frac{1}{2} p(p-1)\right)}^{2}$.

\subsection{Multivariate Exponentially Weighted Moving Average (MEWMA)}

Grafik pengendali MEWMA digunakan untuk mendeteksi adanya perubahan mean proses. Kelebihannya adalah robust terhadap asumsi distribusi normal. MEWMA merupakan generalisasi dari proses untuk data univariat EWMA. Menurut Montgomery (2009), MEWMA yang didefinisikan sebagai berikut

$$
\mathbf{Z}_{j}=\lambda \mathbf{X}_{j}+(1-\lambda) \mathbf{Z}_{j-1}
$$

dengan nilai $0 \leq \lambda \leq 1, j=1,2, \ldots, n$

$\mathrm{Z}_{i 0}:$ matriks 0 dan berukuran $p \times 1$

$\mathbf{Z}_{\mathbf{j}-\mathbf{1}}$ : matriks berukuran $p \times \mathbf{1}$

$p:$ banyak variate yang diamati

$\lambda$ : besarnya pembobot

$\mathbf{X}_{\mathbf{j}}$ : vektor sampel pengamatan ke-j dengan $\mathbf{j}=1,2, \ldots, n$ (banyak pengamatan yang dilakukan) dengan ukuran matriks $p \times 1$

Pada grafik pengendali ini dapat digunakan nilai pembobot yang sama atau tidak untuk masing-masing karakteristik kualitas. Apabila tidak ada alasan pemilihan pembobot yang berbeda untuk masing-masing karakteristik kualitas maka pembobot $\lambda$ bernilai sama. Nilai $\lambda$ ditentukan dengan menggunakan trial and error, dan $\lambda$ yang dipilih adalah nilai $\lambda$ yang menghasilkan grafik dalam keadaan terkendali. Titik pengamatan yang diplotkan di grafik pengendali adalah

$$
T_{j}^{2}=\mathbf{Z}_{\mathbf{j}}^{T} \Sigma_{\mathbf{Z}_{\mathbf{j}}}^{-1} \mathbf{Z}_{\mathbf{j}} ; j=1,2, \ldots, n
$$

dengan

$$
\Sigma_{\mathbf{z}_{j}}=\frac{\lambda}{2-\lambda}\left[1-(1-\lambda)^{2 j}\right] \Sigma
$$


dengan $\boldsymbol{\Sigma}$ merupakan matriks variansi-kovariansi dari data yang sudah distandarisasi. Matriks kovarian ini analog dengan varians pada data univariat EWMA (Montgomery, 2009). Batas kendali pada grafik pengendali MEWMA yaitu Batas Kendali Atas yang dirumuskan

$$
B K A=\overline{T_{j^{2}}}+3 S_{T^{2}}
$$

dengan

$\overline{T_{j^{2}}}$ adalah rata-rata dari $T_{j}^{2}$

$S_{T^{2}}$ adalah standar deviasi dari $T_{j}^{2}$

Batas Pengendali Bawah (BPB) sama dengan 0 karena nilai $T_{j}^{2}$ yang selalu positif. Pembuatan grafik pengendali MEWMA dengan cara membuat plot-plot $T_{j}^{2}$. Proses dikatakan tidak terkendali apabila terdapat nilai $T_{j}^{2}>$ BPA.

\subsection{Grafik Pengendali Kernel Multivariat}

Estimasi densitas kernel adalah teknik nonparametrik untuk mengestimasi densitas dengan fungsi densitas peluang. Tujuan mengestimasi densitas adalah untuk mengambil sampel data yang diketahui dan membuat kesimpulan tentang fungsi densitas peluang.

\subsubsection{Fungsi Kernel}

Misalkan $\boldsymbol{x}_{\boldsymbol{1}}, \boldsymbol{x}_{2}, \ldots, \boldsymbol{x}_{\boldsymbol{p}}$ menjadi sampel vektor acak p-variate yang diambil dari suatu populasi dengan fungsi densitas $f$. Menurut Duong dan Hazelton (2003), Estimasi fungsi densitas kernel didefinisikan sebagai

$$
\hat{f}(\mathbf{x} ; \mathbf{H})=\frac{1}{n} \sum_{i=1}^{n} K_{\mathbf{H}}\left(\mathbf{x}-\mathbf{x}_{i}\right),-\infty<\mathbf{x}_{\mathbf{i}}<\infty(i=1,2, \ldots, \mathrm{n})
$$

dengan

n adalah ukuran sampel;

$\mathbf{H}$ adalah parameter pemulus (bandwidth) $p x p$ matriks yang simetris dan positif;

$\mathbf{x}=\left[x_{1}, x_{2}, \ldots, x_{p}\right]^{T}$ adalah titik, tempat, atau lokasi estimasi;

$\mathbf{x}_{i}=\left[x_{i 1}, x_{i 2}, \ldots, x_{i p}\right]^{T}$ untuk $i=1,2, \ldots, n$;

$\mathrm{K}$ adalah fungsi kernel yang merupakan fungsi densitas peluang, dan $K_{\mathbf{H}^{(x)}}=|\mathbf{H}|^{-1 / 2} K\left(\mathbf{H}^{-1} x\right)$. Menurut Wand (1993), distribusi kernel normal standard multivariat dapat dirumuskan dengan $K(x)=(2 \pi)^{-1} \exp \left(-\frac{1}{2} x^{T} x\right)$.

\subsubsection{Pemilihan Matriks Bandwidth Optimal}

Fungsi kernel mempunyai suatu parameter penghalus yang berguna untuk mengatur derajat kehalusan untuk penghalus kernel yang disebut dengan bandwidth $(\mathbf{H})$. Dalam memilih matriks bandwidth optimal, terdapat metode lain yang sering digunakan, yaitu Cross Validation (CV). Menurut Duong (2007), pada metode Cross Validation (CV) dikembangkan lagi menjadi Smoothed Cross Validation (SCV). Smoothed cross validation (SCV) dapat dicari dengan rumus

$$
\operatorname{SCV}(\mathbf{H})=n^{-1}(4 \pi)^{-p / 2}|\mathbf{H}|^{-1 / 2}+n^{-2} \sum_{i=j}^{n} \sum_{j=1}^{n}\left(K_{2 \mathbf{H}+2 \mathbf{G}}-2 K_{\mathbf{H}+2 \mathbf{G}}+K_{2 \mathbf{G}}\right)\left(\mathbf{X}_{i}-\mathbf{X}_{j}\right)
$$

dengan $\hat{\mathbf{H}}_{S C V}=\arg \min _{\mathbf{H} \in F} S C V(\mathbf{H})$ adalah estimasi metode SCV. 


\subsubsection{Kontur Estimasi Densitas Kernel Multivariat}

Kontur dibentuk dari nilai estimasi densitas kernel (level). Berikut merupakan kontur estimasi densitas kernel yang ditunjukkan oleh Gambar 2. Kontur berwarna sesuai dengan wilayah terkecil yang berisi massa probabilitas yang terdiri dari : merah $=25 \%$, oranye + merah $=50 \%$, kuning + oranye + merah $=75 \%$, dengan demikian bahwa satu wilayah pusat tunggal berisi densitas tertinggi.

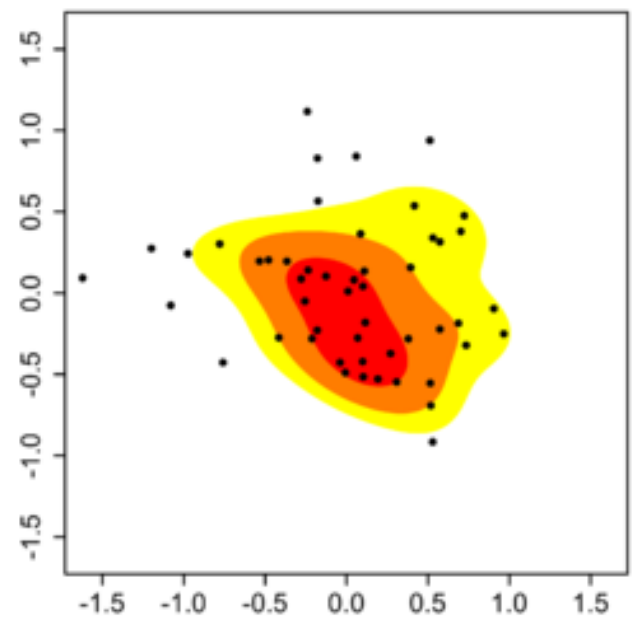

\section{Gambar 1. Kontur estimasi densitas kernel multivariat}

Menurut Pattihahuan (2012), setiap titik sampel yang berada di dalam kontur dianggap terkendali dan jika terdapat titik sampel yang berada diluar kontur maka akan dianggap tidak terkendali.

\subsection{Analisis Kapabilitas Proses}

Kapabilitas proses merupakan suatu pengukuran yang digunakan untuk mengevaluasi keseluruhan proses. Indeks kapabilitas yang disarankan oleh Automotive Industry Action Group (AIAG) untuk proses dalam keadaan in control adalah $\mathrm{C}_{\mathrm{pm}}$ dan $\mathrm{C}_{\mathrm{pmk}}$, sedangkan untuk proses yang tidak dalam keadaan in control, lebih baik digunakan indeks kinerja proses $\mathrm{P}_{\mathrm{pm}}$ dan $\mathrm{P}_{\mathrm{pmk}}$ (Montgomery,2009). Multivariate Proses Capability Indices (MPCI) menunjukkan seberapa baik sebuah proses manufaktur dapat menemui batas spesifikasi ketika karakteristik kualitas memiliki korelasi. Suatu proses produksi berjalan secara capable apabila nilai $C_{\mathrm{pm}} \geq 1$. Perhitungan indeks $\mathrm{C}_{\mathrm{pm}}$ dan $\mathrm{C}_{\mathrm{pmk}}$ untuk data univariat adalah :

$$
\begin{gathered}
C_{p m}\left(X_{1}\right)=\frac{U S L_{X_{i}}-L S L_{X_{i}}}{6 \sqrt{\sigma_{X_{i}}^{2}+\left(\mu_{X_{i}}-T_{X_{i}}\right)^{2}}} \\
C_{p m k}\left(X_{1}\right)=\min \left\{\frac{U S L_{X_{i}}-\hat{\mu}_{X_{i}}}{3 \sqrt{\sigma_{X_{i}}^{2}+\left(\mu_{X_{i}}-T_{X_{i}}\right)^{2}}}, \frac{\hat{\mu}_{X_{i}}-L S L_{X_{i}}}{3 \sqrt{\sigma_{X_{i}}^{2}+\left(\mu_{X_{i}}-T_{X_{i}}\right)^{2}}}\right\}
\end{gathered}
$$

Sehubungan dengan adanya dua karakteristik kualitas yang digunakan dalam penelitian ini, maka indeks kinerja proses secara multivariat cocok digunakan terutama dengan mempertimbangkan pembobot dari masing-masing karakteristik kualitas, dapat dihitung dengan persamaan sebagai berikut (Raissi, 2009): 


$$
\begin{gathered}
M C_{p m}=\sum_{i=1}^{p} W_{i} C_{p m}\left(X_{i}\right) \\
M C_{p m k}=\sum_{i=1}^{p} W_{i} C_{p m k}\left(X_{i}\right)
\end{gathered}
$$

dengan $\mathrm{MC}_{\mathrm{PM}}, \mathrm{MC}_{\mathrm{PMK}}$ berturut-turut merupakan $\mathrm{C}_{\mathrm{PM}}, \mathrm{C}_{\mathrm{PMK}}$ multivariat dengan $\mathrm{W}_{\mathrm{i}}$ merupakan pembobot berdasarkan kepentingan dengan $\sum_{i=1}^{p} W_{i}=1$. Nilai $\mathrm{W}_{\mathrm{i}}$ disesuaikan dengan pembobot karakteristik kualitas yang ditetapkan oleh perusahaan. Jika tidak ada pembobotan untuk masing-masing karakteristik kualitas maka nilai pembobot dianggap sama.

\section{METODE PENELITIAN}

Jenis data yang digunakan dalam penelitian ini berupa data primer yaitu data yang diperoleh secara langsung dari sumber asli atau pihak pertama. Sumber data untuk mendukung penelitian ini adalah 60 sampel data rata-rata panjang dan lebar sarung yang diproduksi di PT Sukorintex. Variabel penelitian yang di teliti adalah karakteristik sarung $\mathbf{X}$ yang tercermin dalam 2 variate yaitu rata-rata panjang $\left(X_{1}\right)$ dan rata-rata lebar $\left(X_{2}\right)$ sarung jenis 30 STR pada proses pemotongan di departemen Packaging. Dalam melakukan pengolahan data penulis menggunakan paket program Microsoft Excel 2016 dan R 3.5.0.

\section{HASIL DAN PEMBAHASAN}

\subsection{Deskripsi Data}

Sebelum melakukan analisis pengendalian kualitas sarung tenun WADIMOR di PT SUKORINTEX terlebih dahulu perlu untuk mengetahui karakteristik dari variate-variate yang diamati. Karakteristik kualitas yang diamati adalah rata-rata panjang $\left(\mathrm{X}_{1}\right)$ dan ratarata lebar $\left(\mathrm{X}_{2}\right)$ sarung dalam satuan $\mathrm{cm}$. Deskripsi karakteristik sarung dapat dilihat pada Tabel 2.

Tabel 2. Deskripsi Karakteristik Kualitas

\begin{tabular}{cccc}
\hline Variate & Rata-rata & Varian & St.Dev \\
\hline Panjang $\left(\mathrm{X}_{1}\right)$ & 220.863 & 2.69595 & 1.64194 \\
\hline Lebar $\left(\mathrm{X}_{2}\right)$ & 125.3195 & 0.11651 & 0.34133 \\
\hline
\end{tabular}

\subsection{Asumsi Multinormal}

Uji asumsi normalitas multivariat dilakukan menggunakan $q-q$ plot atau scatter-plot dari nilai $\mathrm{d}_{\mathrm{j}}^{2}$ dan $\mathrm{q}_{\mathrm{j}}$ dengan bantuan software Microsoft Excel 2016 dan R 3.5.0 diperoleh $q-q$ plot atau scatter-plot yang disajikan pada Gambar 2.

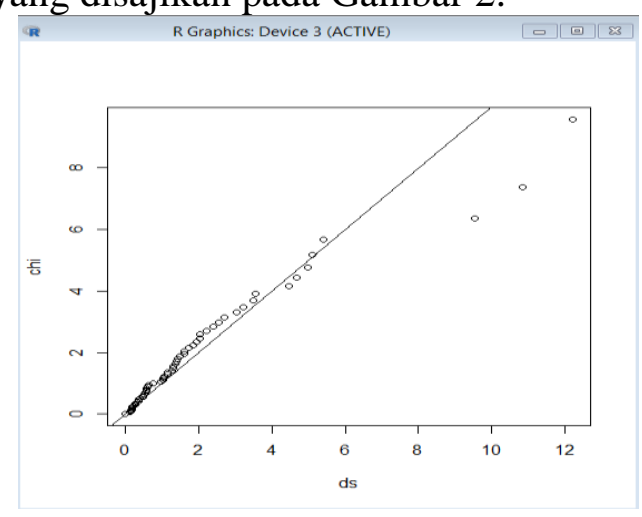

Gambar 2. Plot Normal Multivariat 
Berdasarkan plot normal multivariat yang ditunjukkan oleh Gambar 4, dapat disimpulkan bahwa plot normal multivariat $\left(\mathrm{d}_{\mathrm{j}}{ }^{2}, \mathrm{q}_{\mathrm{j}}\right)$ cenderung membentuk garis lurus. Sehingga secara visual, data berdistribusi normal multivariat. Kemudian berdasarkan hasil perhitungan, dari 60 pengamatan terdapat 34 pengamatan atau lebih dari $50 \%$ nilai $\mathrm{d}_{\mathrm{j}}^{2}$ lebih kecil dari nilai $\chi_{2,0.50}^{2}$. Maka dapat diasumsikan data karakteristik kualitas sarung berdistribusi normal (Haryatmi dan Guritno, 2008).

\subsection{Uji Korelasi Variate}

Untuk menguji ada tidaknya keterkaitan antar variate, maka dilakukan uji Bartlett.

Nilai statistik uji yang diperoleh yaitu

$\chi_{\text {hitung }}^{2}=9.49727$

p-value $=0,002058$

$\mathrm{H}_{0}$ ditolak, karena nilai $\chi_{\text {hitung }}^{2}$ sebesar $9.49727>\chi_{(0.05,1)}^{2}$ sebesar 3.84 dan $p$-value bernilai $0,002058<\alpha$ sebesar 0,05 . Dapat disimpulkan kedua variate pada karakteristik kualitas sarung tenun terdapat korelasi.

\subsection{Grafik Pengendali MEWMA}

Penerapan grafik pengendali MEWMA menggunakan software $\mathrm{R} 3.5 .0$ dan Microsoft Excel 2016 untuk perhitungan manualnya. Untuk menghitung nilai $Z_{j}$, terlebih dahulu menstandarkan data. Nilai awal $Z_{0}=0$ dan besar pembobot $\lambda=0,1$ dengan banyaknya pengamatan yang dilakukan adalah 60 . Nilai $Z_{j}$ pada periode pertama yaitu

$$
\begin{aligned}
& \mathbf{Z}_{1}=\lambda \mathbf{X}_{1}+(1-\lambda) \mathbf{Z}_{0}, \text { dengan } Z_{0}=0 \\
& \mathbf{Z}_{1}=0.1\left[\begin{array}{c}
-0.02619 \\
0.32666
\end{array}\right]+(1-0.1) 0 \\
& \mathbf{Z}_{1}=\left[\begin{array}{c}
-0.0026 \\
0.03267
\end{array}\right]
\end{aligned}
$$

Menghitung matriks varian-kovarian dari $Z_{1}$ diperoleh

$$
\begin{aligned}
& \Sigma_{\mathbf{Z}_{1}}=\frac{\lambda}{2-\lambda}\left[1-(1-\lambda)^{2 \times 1}\right] \Sigma \\
& \Sigma_{\mathbf{Z}_{1}}=\left[\begin{array}{cc}
0.01 & 0.0003871 \\
0.003871 & 0.01
\end{array}\right]
\end{aligned}
$$

untuk perhitungan titik pengamatan pada grafik pengendali MEWMA diperoleh $T_{1}^{2}=\mathbf{Z}_{1}^{T} \Sigma_{\mathbf{Z}_{1}}^{-1} \mathbf{Z}_{1}$

$$
T_{1}^{2}=\left[\begin{array}{ll}
-0.0026 & 0.03267
\end{array}\right]\left[\begin{array}{ll}
117.6268 & -45.5344 \\
-45.5344 & 117.6268
\end{array}\right]\left[\begin{array}{l}
-0.0026 \\
0.03267
\end{array}\right]
$$

$T_{1}^{2}=0.13411$

Proses perhitungan dilanjutkan dengan langkah dan cara yang sama hingga diperoleh nilai titik pengamatan terakhir yaitu $T_{60}^{2}=3.47701$. Untuk mengetahui nilai $T_{j}^{2}$ pada semua pengamatan dengan cara yang sama menggunakan nilai $\lambda$ yaitu 0.1 . Kemudian membuat grafik pengendali MEWMA dengan menggunakan pembobot $\lambda=0,1$ sehingga diperoleh nilai batas kendali atas (BKA) sebesar 14.62943 dan batas kendali bawah (BKB) sama dengan 0 karena nilai $T_{j}^{2}$ yang selalu positif. Menggunakan software R 3.5.0 grafik pengendali tersebut ditunjukkan pada Gambar 3. 


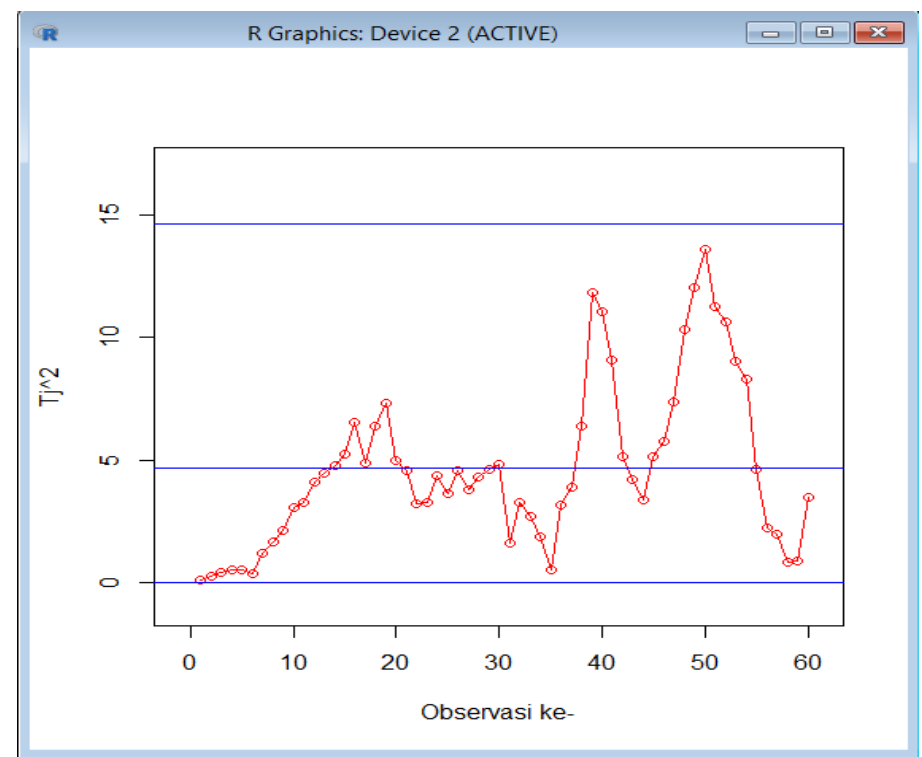

Gambar 3. Grafik Pengendali MEWMA dengan $\lambda=0.1$

Berdasarkan Gambar 3 dapat diketahui bahwa dari 60 sampel data memiliki nilai $T_{j}^{2}$ berada di antara batas-batas kendali. Menurut Montgomery (2009), semakin kecil nilai $\lambda$ akan lebih efektif dalam mendeteksi pergeseran mean proses yang kecil. Maka dapat dikatakan bahwa grafik pengendali MEWMA terkendali secara statistik. Selain itu, grafik pengendali MEWMA ini sensitif terhadap pergeseran proses yang kecil, dilihat dari nilai $\lambda$ yang mendekati nilai 0 .

\subsection{Grafik Pengendali Kernel Multivariat}

Estimasi densitas kernel multivariat dilakukan dengan bantuan software $\mathrm{R}$ 3.5.0. Metode yang digunakan untuk menentukan bandwidth $(\mathbf{H})$ yaitu menggunakan metode Smooted Cross Validation (SCV). Nilai bandwidth $(\mathbf{H})$ ditentukan dengan packages ks:

$$
\mathbf{H}=\left[\begin{array}{ll}
0.66145829 & 0.06878419 \\
0.06878419 & 0.02355263
\end{array}\right]
$$

Nilai $\mathbf{H}$ digunakan untuk mencari nilai dari fungsi densitas kernel multivariat. Nilai fungsi densitas kernel untuk koordinat ke-1 dinyatakan dalam $\mathbf{x}=\left[\begin{array}{lll}220.82 & 125.43\end{array}\right]$ yaitu

$$
\begin{aligned}
& \hat{f}(\mathbf{x} ; \mathbf{H})=\frac{1}{n} \sum_{i=1}^{n} \frac{1}{2 \pi \sqrt{|\mathbf{H}|}} e^{-\frac{1}{2}\left(\mathbf{x}-\mathbf{x}_{i}\right)^{T} \mathbf{H}^{-1}\left(\mathbf{x}-\mathbf{x}_{i}\right)}
\end{aligned}
$$

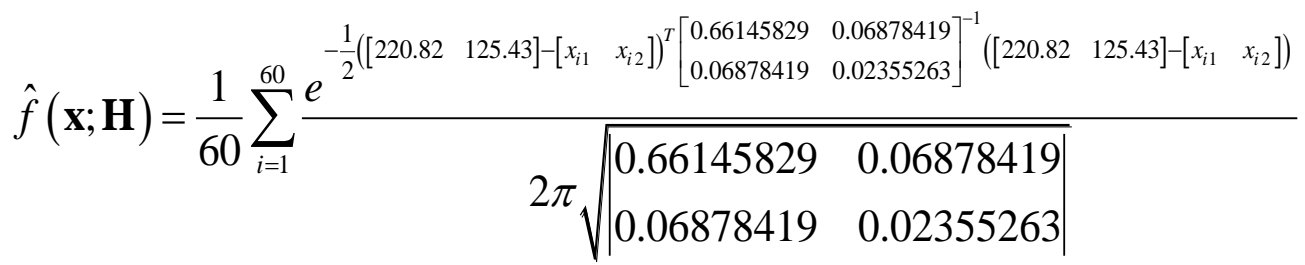

$$
=0.252865
$$

Diperoleh nilai densitas kernel di titik $\mathbf{x}=\left[\begin{array}{ll}220.82 & 125.43\end{array}\right]$ sebesar 0.252865. Berdasarkan output software R 3.5.0 nilai batas level sebesar 0.06130611 dengan tingkat signifikansi $\alpha=0.1$ didapatkan kesimpulan bahwa titik koordinat ke-1 berada dalam kontur karena nilai 
densitas kernelnya lebih besar dari nilai batas level. Proses perhitungan manual dilanjutkan hingga titik koordinat ke-60.

Data sarung tenun WADIMOR jenis 30 STR dibuat grafik pengendali dari estimasi densitas kernel untuk data multivariat yang ditunjukkan pada Gambar 4.

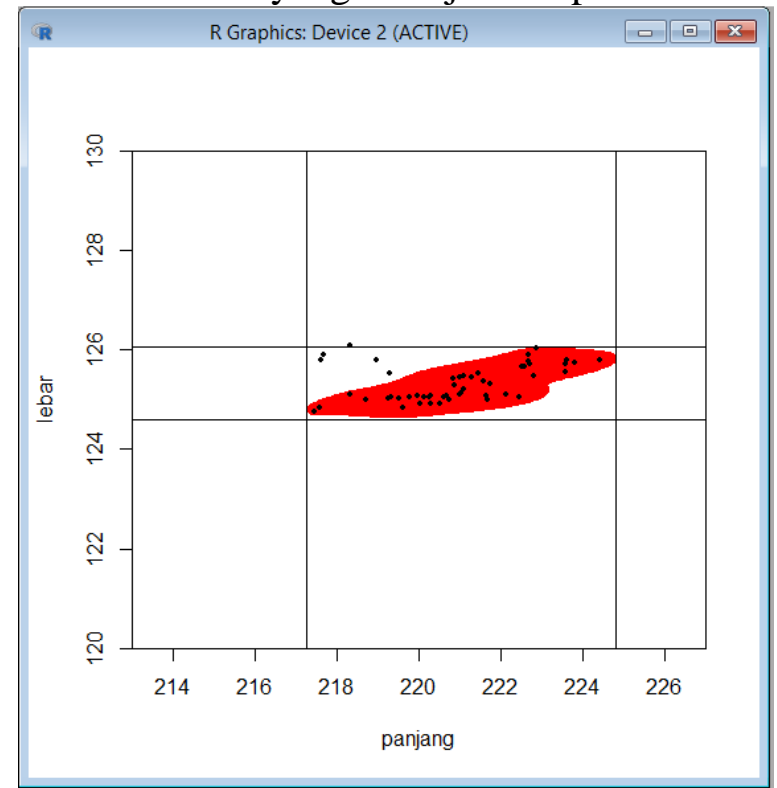

Gambar 4. Kontur estimasi densitas kernel multivariat dengan $\alpha=0.1$

Pada Gambar 4 kontur merah menunjukkan luasan estimasi densitas kernel multivariat. Titik-titik hitam merupakan persebaran data rata-rata panjang dan lebar sarung tenun WADIMOR jenis 30 STR. Batas spesifikasi menggunakan nilai estimasi densitas kernel (level) sebesar 0.06130611 dengan tingkat signifikansi $\alpha=0.1$. Data sarung tenun WADIMOR jenis 30 STR dikatakan terkendali jika setiap pengamatan berada didalam kontur merah. Berdasarkan output software R 3.5.0 data panjang dan lebar sarung tenun WADIMOR jenis 30 STR tidak terkendali karena terdapat data yang berada diluar wilayah kontur yang berwarna merah.

Berdasarkan Gambar 4 yang menyimpulkan grafik pengendali kernel multivariat tidak terkendali, maka dilakukan perbaikan dengan memilih $\alpha$ secara trial and error. Grafik pengendali kernel multivariat terkendali pada $\alpha=0.01$ yang ditunjukkan oleh Gambar 5. 


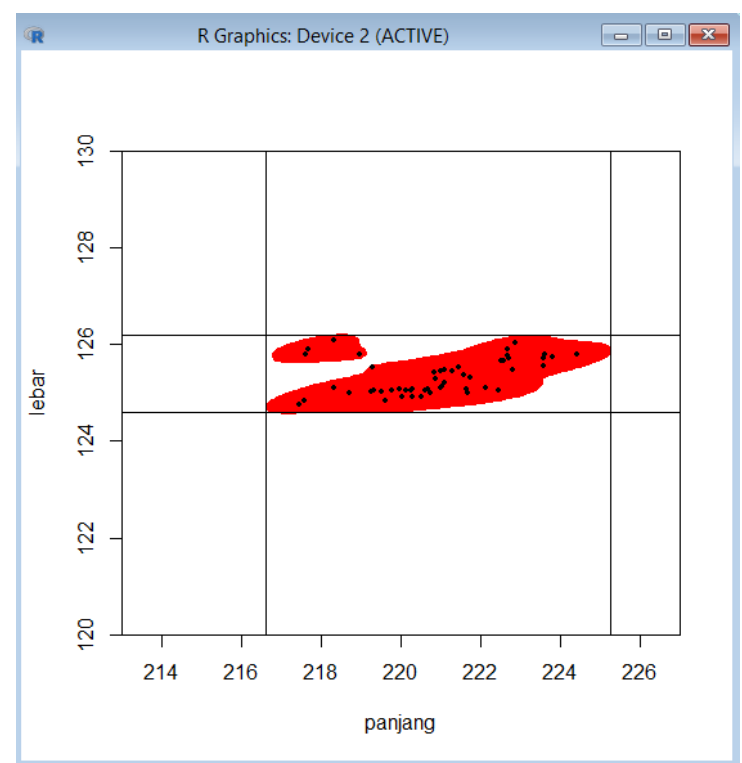

Gambar 5. Kontur estimasi densitas kernel multivariat dengan $\alpha=0.01$

Pada Gambar 5 terlihat bahwa data rata-rata panjang dan lebar sarung tenun WADIMOR jenis 30 STR sudah berada dalam wilayah kontur yang ditunjukkan dengan warna merah, sehingga dapat dikatakan proses sudah terkendali. Namun, dilihat dari tingkat signifikansi atau nilai $\alpha$ yang mendekati 0 pada proses menandakan bahwa grafik pengendali kernel multivariat tidak stabil dalam pengendalian kualitas produk, karena semakin kecil tingkat signifikansi maka semakin banyak data yang masuk dalam daerah penerimaan. Dari segi ekonomi akan menguntungkan perusahaan namun akan merugikan konsumen dan kualitas produk pada perusahaan tersebut akan berkurang.

\subsection{Perbandingan Grafik Pengendali Parametrik dan Nonparametrik}

Pengendalian kualitas data rata-rata panjang dan lebar sarung tenun WADIMOR jenis 30 STR lebih baik jika menggunakan grafik pengendali MEWMA. Hal ini dikarenakan grafik pengendali dinyatakan sudah terkendali pada MEWMA dengan $\lambda=0.1$ dan grafik pengendali kernel multivariat dengan tingkat signifikansi 0.1 dinyatakan tidak terkendali. Ketika dilakukan perbaikan grafik pengendali kernel multivariat dengan trial and error diperoleh tingkat signifikansi 0.01 yang menghasilkan grafik yang terkendali. Namun demikian, grafik pengendali kernel multivariat tidak stabil dalam pengendalian kualitas produk, karena semakin kecil tingkat signifikansi maka semakin banyak data yang masuk dalam daerah penerimaan.

\subsection{Analisis Kapabilitas Proses Grafik Pengendali MEWMA}

Berdasarkan analisis pada MEWMA, data dinyatakan sudah terkendali, sehingga dapat dilakukan analisis untuk kapabilitas proses. Nilai spesifikasi untuk panjang sarung yaitu $220 \pm 5 \mathrm{~cm}$ dan untuk lebar sarung yaitu $125 \pm 5 \mathrm{~cm}$. Nilai USL dan LSL ditentukan berdasarkan spesifikasi target atas dan bawah dari PT Sukorejo Indah Textile yang telah distandarkan, disesuaikan dengan z-score yang ditunjukkan pada Tabel 3.

Tabel 3. Batas spesifikasi karakteristik kualitas terstandarisasi

\begin{tabular}{ccc}
\hline Variate & USL & LSL \\
\hline Panjang $\left(\mathrm{X}_{1}\right)$ & 2.5196 & -3.5708 \\
\hline Lebar $\left(\mathrm{X}_{2}\right)$ & 13.7154 & -15.5816
\end{tabular}

Mengitung $\mathrm{C}_{\mathrm{pm}}$ dan $\mathrm{C}_{\mathrm{pmk}}$ univariat dengan rumus dari persamaan (8) dan (9), untuk data rata-rata panjang sarung diperoleh hasil 


$$
\begin{aligned}
C_{p m}\left(X_{1}\right) & =\frac{U S L_{X_{i}}-L S L_{X_{i}}}{6 \sqrt{\sigma_{X_{i}}^{2}+\left(\mu_{X_{i}}-T_{X_{i}}\right)^{2}}} \\
& =\frac{2.5196-(-3.5708)}{6 \sqrt{1.276}} \\
& =0.8985 \\
C_{p m k}\left(X_{1}\right) & =\min \left\{\frac{U S L_{X_{i}}-\hat{\mu}_{X_{i}}}{3 \sqrt{\sigma_{X_{i}}^{2}+\left(\mu_{X_{i}}-T_{X_{i}}\right)^{2}}}, \frac{\hat{\mu}_{X_{i}}-L S L_{X_{i}}}{3 \sqrt{\sigma_{X_{i}}^{2}+\left(\mu_{X_{i}}-T_{X_{i}}\right)^{2}}}\right\} \\
& =\min \left\{\frac{2.5195}{3 \sqrt{1.276}}, \frac{15.5816}{3 \sqrt{1.276}}\right\} \\
& =0.7434
\end{aligned}
$$

untuk data rata-rata lebar sarung diperoleh hasil

$$
\begin{aligned}
C_{p m}\left(X_{2}\right) & =\frac{U S L_{X_{i}}-L S L_{X_{i}}}{6 \sqrt{\sigma_{X_{i}}^{2}+\left(\mu_{X_{i}}-T_{X_{i}}\right)^{2}}} \\
& =\frac{13.7154-(-15.5816)}{6 \sqrt{1.871}} \\
& =3.57 \\
C_{p m k}\left(X_{2}\right) & =\min \left\{\frac{U S L_{X_{i}}-\hat{\mu}_{X_{i}}}{3 \sqrt{\sigma_{X_{i}}^{2}+\left(\mu_{X_{i}}-T_{X_{i}}\right)^{2}}}, \frac{\hat{\mu}_{X_{i}}-L S L_{X_{i}}}{3 \sqrt{\sigma_{X_{i}}^{2}+\left(\mu_{X_{i}}-T_{X_{i}}\right)^{2}}}\right\} \\
& =\min \left\{\frac{13.7254}{3 \sqrt{1.871}, \frac{15.5816}{3 \sqrt{1.871}}}\right\} \\
& =3.3426
\end{aligned}
$$

Setelah dilakukan analisis kapabilitas secara univariat dilakukan perhitungan nilai $\mathbf{M C}_{\mathrm{pm}}$ dan $\mathrm{MC}_{\mathrm{pmk}}$ dengan nilai indeks $\mathrm{C}_{\mathrm{pm}}$ dan $\mathrm{C}_{\mathrm{pmk}}$ yang telah dihitung.

$$
\begin{aligned}
M C_{p m} & =\sum_{i=1}^{p} W_{i} C_{p m}\left(X_{i}\right) \\
& =((0.5 \times 0.8985)+(0.5 \times 3.57)) \\
& =2.2343 \\
M C_{p m k} & =\sum_{i=1}^{p} W_{i} C_{p m k}\left(X_{i}\right) \\
& =((0.5 \times 0.7434)+(0.5 \times 3.3426)) \\
& =2.043
\end{aligned}
$$

Berdasarkan hasil analisis secara multivariat nilai $\mathrm{MC}_{\mathrm{pm}}=2.2343$ dan nilai $\mathrm{MC}_{\mathrm{pmk}}$ $=2.043$ lebih besar dari 1 yang menandakan bahwa secara multivariat kinerja proses sudah baik pada kedua variat data. Jadi dapat disimpulkan bahwa kapabilitas proses grafik pengendali MEWMA pada data sarung tenun WADIMOR jenis 30 STR sudah kapabel.

\section{KESIMPULAN}

Berdasarkan analisis yang telah dilakukan diperoleh kesimpulan bahwa:

1. Grafik pengendali MEWMA dengan $\lambda=0.1$ dikatakan stabil dan terkendali karena data berada di antara batas kendali. Pada grafik pengendali kernel multivariat dengan tingkat signifikansi 0.1 diperoleh bahwa grafik pengendali kernel 
multivariat dikatakan tidak terkendali karena terdapat data yang berada diluar kontur merah. Maka dilakukan perbaikan grafik pengendali dengan trial and error. Grafik dinyatakan terkendali pada tingkat signifikansi 0.01 dengan level sebesar 0.03125701 .

2. Nilai kapabilitas proses untuk grafik pengendali MEWMA lebih dari 1, sehingga menunjukkan proses multivariat pada produk sarung tenun WADIMOR jenis 30 STR sudah kapabel. Selain itu, dalam praktiknya pun proses produksi sarung sudah dianggap berjalan dengan lancar dan sistem produksi sudah terorganisir dengan baik.

3. Pada pengendalian kualitas data sarung tenun WADIMOR jenis 30 STR, jika asumsi multinormal terpenuhi, maka grafik pengendali parametrik Multivariate Exponentially Weighted Moving Average (MEWMA) lebih baik dari pada grafik pengendali nonparametrik kernel multivariat.

\section{DAFTAR PUSTAKA}

Assauri, S. 1980. Management Produksi. Jakarta: Fakultas Ekonomi Universitas Indonesia.

Duong, T. dan Hazelton, M.L. 2003. Plug-In Bandwidth Matrices for Bivariate Kernel Density Estimation. Journal of Nonparametric Statistics Hal. 17-30. doi:10.1080/10485250306039.

Duong, T. 2007. Ks: Kernel Density Estimation and Kernel Discriminant Analysis for Multivariate Data in R. Journal of Statistical Software. Vol. 21, Issue 7.

Haryatmi, S. dan Guritno, S. 2008. Metode Statistika Multivariat. Jakarta: Universitas Terbuka.

Montgomery, D.C. 1990. Pengantar Pengendalian Kualitas Statistik. Alih bahasa: Zanzawi Soejoeti. Gadjah Mada University Press, Yogyakarta. Terjemahan dari: Introduction to Statistical Quality Control. John Wiley \& Sons, Inc.

Montgomery, D.C. 2009. Statistical Quality Control, Sixth Edition Singapore: John Wiley $\&$ Sons.

Morrison, D. 1990. Multivariate Statistical Methods (Third Edition). New York: Mc Graw Hill Publishing Company.

Pattihahuan, S., Setiawan, A., dan Sasongko, L.R. 2012. Penerapan Grafik Pengendali Berdasarkan Estimasi Fungsi Densitas Kernel Bivariat. Seminar Nasional Pendidikan Matematika. ISBN: 978-979-17763-5-6.

Raissi, S. 2009. Multivariate Process Capability Indices On The Presence Of Priority For Quality Characteristics. Journal of Industrial Engineering, Vol. 5, No.9: Hal. 27-36

Wand, M.P. dan Jones, M.C. 1993. Comparison of Smoothing Parameterizations in Bivariate Kernel Density Estimation. Journal of the American Statistical Association. $88: 442,520-528$. 